University of Louisville

ThinkIR: The University of Louisville's Institutional Repository

Electronic Theses and Dissertations

$1-1926$

\title{
The farce element in Moliere.
}

Louise Diecks

University of Louisville

Follow this and additional works at: https://ir.library.louisville.edu/etd

\section{Recommended Citation}

Diecks, Louise, "The farce element in Moliere." (1926). Electronic Theses and Dissertations. Paper 344. https://doi.org/10.18297/etd/344

This Master's Thesis is brought to you for free and open access by ThinkIR: The University of Louisville's Institutional Repository. It has been accepted for inclusion in Electronic Theses and Dissertations by an authorized administrator of ThinkIR: The University of Louisville's Institutional Repository. This title appears here courtesy of the author, who has retained all other copyrights. For more information, please contact thinkir@louisville.edu. 
UNIVERSITY OF LOUISVILLE

THE FARCE ELEMENT IN MOLIERE

A DISSERTATION

SUBMITTED TO THE FACULTY

OF THE GRADUATE SCHOOL OF ARTS AND SCIENCES

IN PARTIAL FULFILLMENT OF THE

REQUIREMENTS FOR THE DEGREE

OF MASTER OF ARTS

DEPARTMENT OF ROMANCE LANGUAGES.

BY

LOUISE DIECKS

1926 
IN TRODUCTION 
To gain a true appreciation of the works of any author, we must first be familiar with his race, his environment, and the period in which and of which he wrote. The Paris of the early seventeenth century was far different from the modern metropolis of to-day. It was the Paris of ill-paved, badly lighted streets where beggar and peasant starved and marquises rolled by in their emblazoned coaches, where d'Artagnan and the King's musketeers spread romance and challenged authority and where conspiracy brewed and criminals died upon the pillory. It was a pleasure-loving and pleasure-seeking, merry, carefree populace in spite of the iron rule of Richelieu, the crimes of the Fronde and the wars of Louis XIV.

In the heart of this Paris lived Molière; for it was just around the corner from the market place that his father, Jean Poquelin, kept his shop where the young Jean Baptiste served his apprenticeship as valet de chambre tapissier, an honorable and lucrative office. Moliere, or rather Jean Baptiste Poquelin - the name of Moliere was not adopted until the formation of his l'Illustre Theatre - had but to turn the corner to see richly dressed 
merchants barter their merchandise, and to hear market women cry their wares. Quite near was the Pont Neuf, the main artery of the city, athrong with people of all sorts. Hurried business men justled leisurely valets and grisettes, while to one side quacks exhibited their drugs or their mountebanks aided them to get customers by their queer antics, and acrobats, clowns, and ballad singers displayed their talents. Here it was that Moliere first acquired a taste for comedy. Every Sunday, Jean Baptiste was wont to spend with his maternal grandfather, Louis Cressé, at his fine country home. Like all good bourgeois, Louis Cressé was fond of the theatre; so it is highly probable that he was often accompanied by his grandson to see the first night performances of the actors of the Hôtel de Bourgogne. Gros-Guillaume was chied fun-maker there, and Guillet-Gorju, wearing an enormous perruke and a bump on his nose showed the boy Poquelin the ridiculous side of medecine by his portrayal of a doctor. At the celebrated fair of Saint Germain des Prés, two booths of which grandfather Cressé owned, mountebanks performed upon improvised stages. And at the Hôtel du Petit Bourbon a different kind of farce, 
the comedy-of-masks, was presented by Scaramouche and his Italian companions. All of these influences together with his training in rhetoric and in the reading and acting of the Latin poets, Terence and Plautus, at the Collège de Clermont provided a good foundation upon which to build a stage to be set for a more refined farce and to attain its zenith of decoration in high comedy . 
THE FARCE ELEMENT IN MOLIERE 
From the Italian and French actors of farce, Molidre received his first impression of the comic drama. French farce was one of the products of the later Middle Ages, and the early Renaissance. Its sole object was to produce immediate laughter, fun for its own sake, often passing beyond the limits of decency in its exuberant gayety. Sometimes these old farces took the form of a monologue as in the bold confession of cowardice in the Franc Archer de Baignolet; or of a dialogue of racy repartee. This species reached its height in Maître Pierre Pathelin with the facetious situations of its varied characters. French farce resembled the fabliaux or ancient tales in verse which treated of clerical misdeeds, or of mismated couples, : or of worthless quack doctors expressed somewhat in the fantastic style and broad humor of Rabelais. Farce, given at the Hôtel de Bourgogne at the beginning of the seventeenth century, at the Marais (by Jodelet), and at the Hôtel du Petit Bourbon (by Scaramouche) was a series of funny pictures often taken from life which a mere semblance of a plot served as a frame. 
A platform set up, often upon an open street with a curtain hung at the back served as a stage. With their slapsticks in their girdles and their faces smeared with flour, the actors undertook to make the public laugh by relying on their ability as fun makers and upon the traditions of their art. Farce did not try to conceal the actor behind the role he played. GrosGuillaume, Turlepin and Scaramouche gave names to their parts; the Vicomte de Jodelet is the Jodelet of the Marais. Not only the same name but a traditional costume was assumed by the farce actor; and he wore either a mask, Italian fashion, or was daubed with powder, French fashion. As Scarron and Corneille came in, these unpretentious little pieces were considered outside the pale of literature and fell into disrepute. When Molière left for the provinces, they were banished from the stage, and upon his return he found that most of the farce actors had died or left the stage. Jodelet alone remained in the Marais.

A Spanish influence was manifest at court during the reign of Louis XIII and in the early years of Louis XIV. The wives of both monarchs were Spanish and 
relations between the two kingdoms were very close. Spanish costumes, language, and literature were the fashion. Spanish comedians were seen in Paris. Molière had many Spanish dramas in his possession which he studied and borrowed from, yet they could have made no deep impression upon him because of their fantastic qualities and their highflown grandiloquence. What he did absorb from them was their delicate grace, which tended to refine his French model, and their "fecundity of invention", which increased the number of his jeux de scène and his quiproquos.

Transplanted to France by traveling

companies, the Italian comedy-of-marks had modified the methods of French farce before Molière left Paris. The originof this comic genre, unwritten, unliterary, improvised had its origin perhaps in the rural farces of the Roman republic. The deviser of the piece, who was at the same time the chief performer, called his actors together, outlined the action to them, and distributed the parts. A scenario or detailed account of the story was then drawn up and hung behind the scenesso that the actors might consult it during the performance. No attempt on the part of the author was made to mould flesh upon the frame or to 
embellish it in any way. This was the work of the actor himself; and as the Italian is good at improvising, it was not a hard task. If the play met with success, its originator sometimes wrote it down and published it.

The actor wore a mask, and a costume which the

was characteristic of/unchanging role he took in every play. During the Renaissance, inhabitants of various regions of Italy had outstanding local peculiarities. There was the Venetian merchant greedy for gain; the artful, and rascally Neapolitan; and the Bolognese pedant, his mouth filled with Latin quotations. One of the types was chosen by the farce actor and made his own for life. The performer had a store of speeches of his own make suitable to the character he always played. The square in front of the house of some one of the actors was chosen as a fit setting so that the zanni if he were of an acrobatic turn might make flying leaps through the windows and soale the balconies. Zanni of the Italian is the English zany or silly-John, a foolish clown. From its diminutive Zannarello came the French Sganarelle, the wily valet of Molière's farces. These zanni were low comedy actors provided with an immense repertory of jests and tricks in addition to their acrobatic talents, and known by the name of Harlequin or Scapin. 
Pantaloon, Columbine, Brighella, Pierrot, and Punch and Judy are their offspring. They reigned for a long time upon all stages both within and without Italy.

In Southern France, Molière again saw the merits of the Italian comedy-of-masks, - its liveliness, its briskeness of action, its unending fun which caused such mirth. His failure in Paris probably taught him that tragedy was not what the people wanted. Their costumes packed in trunks and their trunks, their scenery, and themselves packed pell-mell upon a cart, the troupe of the l'Illustre Theâtre left for the provinces. Tragedy was forever banished from the stage of Moliere; for the first plays produced here were the embodiment of the principles of the Italian comedy-of-masks. Some barn or tennis court with a trestle for a stage, lighted by tallow dips and hung with a back drop of daubed canvas representing a street afforded the buffoon, Molière, with his befloured face and grotesque charcoaled mustachios, ample room to elaborate upon his role and to flaunt his broad jokes to the accompaniment of drum, trumpet and squeeking fiddle.

The first farces performed in the provinoes are of uncertain origin, but may with high probability be attributed to Molière. There were the pedantic type: Ie Maître de I'Ecole, and Gros-René E'colier; and the satirical ones: 1e Docteur Amoureux, Les Trois Docteurs Rivaux, and le Docteur Pédant. Gorgibus dans le Sac, Ie Fagotier and Ia Casaque were also presented. But the best of his repertoire, and most likely 
his own composition were Ie Médecin Volant, and Ia Jalousie du Barbouillé (The Jealousy of Smutty Face). Le Hédecin Volant inspired by the Italian Il Medico Volante was not completely finished. Its original seript shows the word etc., here and there, indicating that the actors filled in the gaps with their own innovations as the Italians were accustomed to do. Both of these farces are quite primitive, and unoriginal, yet characteristic. The story is but a thread upon which to hang episodes of robust fun and vigorous gayety afforded by the fixed types of its characters. The chief oharacter in each one is an intriguing servant, devised for Molière's own acting, who produces fun by multiplying and intensifying the comic situations as the play progresses.

\section{Le Médecin Volant takes its name from the} scene in which Gorgibus, the father, comes unexpedtedly upon Sganarelle dressed as a velot who had been introduced into his home as a physician to attend his daughter. Sganarelle, in reality the wily valet of Valère, the lover, thinks to clear up the predicament by explaining that the mistake is due to the striking resernblance between him and his brother, who is a doctor. Thereupon, he proceeds to play the parts of both valet and doctor. He enters through the door as a valet, and leaps out of the windows as a doctor to return imnediately in the guise of valet and to make his exit through the door as a dootor. 
He disputes with and embraces his brother, that is, with a hat and ruche which was accomplished by foliere's agility as an actor. The dialogue, sprinkled with coarse jests, brings out the humor of the comic situations. The wranglings between a husband, and his wife by whom he believes himself deceived forms the framework for Ia Jalousie du Barbouillé to bo filled in by the funny antics, somewhat vulgar jests, and abundant oaths which proved the delight of an unrefined public. Angelique, the wife, a vulgar rogue becomes the type of rash coquette in Molière's later plays.

\section{Although both of these farces have some} comical, well-written passages, they have no literary merit. But they do show how Molière had mastered the Italian method, and, in addition, a skill in handling the comic situation, and a vigorous vocabulary. Rigal advises the student not to disdain too much these first attempts of the great playwright; for with old French farce and the Italian theatre he fashioned the masterpieces of the French stage. An Italian, Alessandro d'Ancona, after witnessing the decadence of the national theatre, said: "There remains the commedia dell'arte, which still sends off its sparkling firework of repartee and buffoonery. But a stranger, Moliere, knew how to turn to advantage this living, nimble, spontaneous form, and who, by adding to it the study of nature, the passions, and the ancients, will obtain a perfect form." Holière could have had no better practice in dramaturgy than in composing these old farces 
which called for incessant movement, and held speech secondary to action. This was indeed an achievement in view of the fondness of the French for abundant discourse as evidenced in the dramas of Corneille, and Racine, and which tended toward an excess of talk and no briskness of action. According to Grimarest, Molière reached Lyons in 1653. Here his life changed. He ceased to be a stroller. Taking advantage of the departure of the Duke of Epernon's Comedians, the troupe of Molière produced a play which found favor in the eyes of the oritical Lyonnais. A theatrical success in Lyons was not far from a triumph in Paris. L'Etourdi, a farce, in spite of its five acts in rimed alexandrines, was the successful play of Lyons. Founded upon the Itrlian, Nicolo Barbieri's I'Inavvertito (The Imprudent One), and some of its episodes borrowed from other Italian pieces, it was closely patterned after the Italian comedy-of-masks. Its incessant activity, its sudden reversals of situations, its spontaneous fun, its fixed.characters, exaggerated almost to caricature, all these features show the direct influence of the Italian genre. Everything is taken lightly. Even the alleged death of Pandolphe is put in a mocking way.

Mascarille, played by Molière, is chief funmaker, whose sole aim is to provoke laughter. He is the wily valet who combines plans, lays traps, ten times invents ruses which are ten times foiled by his scatterbrained master, Lélie, 
in whose behalf he has planned them. This subject dates back to Plautus; for Mascarille is but a paraphrase of Pseudolus, the knavish slave of Latin comedy which in turn found its source in the clever, roguish slave of the Greek stage, aiding his master by the nimbleness of his wits. Mascarille was a mask for Moliere, that is, a traditional type destined to remain the same in his following works, and which the public gradually associated with the actor who portrayed it. Molière was called Mascarille in Paris for a long time.

Trickery affords Mascarille great enjoyment, who is void of scruples, whose past is uncertain, and who boasts of his many faults. He is artificial enough - and he can afford to be so because the scene is laid in fantastic Messina - to make us laugh at his misdeeds, and absurd and impossible situations without afterthought. Yet Mascarille has already begun to resemble men in spite of his fantasy; for he has talents and vices. Lélie rings true. Not his mere stupidity, but his characteristics of a gentlemen and of an honest man forces him to undo the ruses of Mascarille in the scenes in which he bursts out in youthful protest against the slander of climene, and refuses to let Anselme be robbed of his purse. The contradietions of the character of L'elie, his étourderie (blundering), and his sottise (stupidity) make the play funny. The rest of the cast: Célie, Leandre, Hippolyte, and the oldmen, are simply fantoches (puppets) of old farce. 
L'Etourdi was followed by le Dépit Amoureux, presented in 1659. In really a five act piece, only two acts, the wooings and wranglings of its lovers, was presented for at least a hundred years. Produced under extraordinary oircumstances, this age old theme affords abundant comedy. The love bickerings, of the maid and valet, in addition to those of the hero and heroine, Eraste and Lucile, recall the Spanish comedy with its graciosos (amusing (valets), often buffoonlike echos of their masters' loves and complaints.

$$
\text { Gros-René, the valet, a bon vivant, and }
$$

Marinette, maid, provide the fun with their crossfire of gay invective and gallantry. In Act I, Scene II, they speak of their love as follows:

\section{Marinette.}

What shall we say of our love?

You never speak of it.

$$
\text { Gros-René. }
$$

A marriage desired

Among people like us is soon made.

I want you; will you have me?

Marinette.

With pleasure.

$$
\text { Gros-René. }
$$

Let us shake on that. 
Marinette.

Farewell, Gros-René, my love.

Gros-René.

Farewell, my sun!

Marinette.

Farewell, noble spark of my love!

Gros-Rene.

Farewell, dear comet, rainbow of my sould

No worry nor tragedy enters their love, or their love quarrels. They joke about their engagement. Resorting. to the traditional custom of breaking a straw to make their separation final proves too much for their old friendship, and they are reconciled. Eraste, a tender, respectful, restless lover, and the charming, proud, sensitive Lueile rise above the pale of farce and show Molière's first insight into human nature.

In the three acts which are not represented upon the stage, some of the old Italian farce elements appear: girls disguised as boys, and the consequent difficulties and broad jokes arising from such a situation; a doctor, consulted upon a serious case, who piles up one pedantic observation upon another until he is put to flight by clanking a mule-bell in his ear; a monologue by the valet, Mascarille, transformed into a dialogue with an absent person; and the fiery quarrel 
between the old men, Albert and Polydore. The few good details of this part of the work do not equal, however, the many faults of the literary oomedy which are manifest in it.

Mascarille, the inimitable, appeared in all his glory in Ies Précieuses Ridicules, presented upon the stage of the Petit Bourbon in the fall of 1659. A farce in one act, and in prose, so it seemed; yet, it had some of the signs of social satire, and showed that Moliere was turning away from the external and arbitrary methods of the Italian comedy-of-masks. It showed, too, that is author had shaken himself free of the useless traits of the literary comedy, which in Ie Dépit Amoureux gave cause for fear that Molière was taking a backward step. Farce, brilliant and briskly moving, but cleared of its cobwebs and fogs, opened into full flower in this little masterpiece. It holds the interest because we never know what to expect in its raried scenes.

Gorgibus, the traditional old man, makes his appearance once more to quarrel with his daughter, Magdelon, and his niece, Gathos, for the prudery and frippery, which they have acquired from the précieuses of Paris; and for their refusal to marry two honest men. It is interesting to note 
that the actors La Grange and du Croisy gave their names to the two lovers just as Gros-Guillaume and Scaramouche gave names to their parts.

Cathos and Magdelon come from the provinces for the exaggerations which farce required. Their preciosity is displayed in all its stupidity when the valets of the rejected lovers disguised as noblemen appear upon the scene to court them. Cathos, by way of asking the marquis (Mascarille) to be seated, says: "Please, monsieur, be not inexorable to this armchair which has been extending its arms to you for a quarter of an hour; do satisfy the desire it has to embrace you." After having combed his hair, and arranged his canons (trouser frills), the Marquis de Wascarille exhibits the pedantry and vanity of the précieux, whom he is impersonating, by composing madrigals, singing impromptu songs, and bragging about them and his attire. Says Mascarille: "You say nothing of my plumes! What do you think of them?"

$$
\begin{aligned}
& \text { "Frightfully beautiful", answers Cathos. } \\
& \text { Mascarille continues, "Do you know what this }
\end{aligned}
$$

feather cost me? A gold louis. You know, I have a mania for getting everything of the finest." Then, he asks what they think of his ribbons, and his canous, admitting himself they are well chosen. And Hagdelon admits that they are "furiously becoming". Calling hats, "Defiers of the weather", chairs, 
"Indispensables of conversation"; the teeth, "the furniture of the mouth", and the ears, "gates of understanding", the two girls cause abundant laughter.

Profuse laughter must have greeted the appearance of the Mascarille of Molière, who wore in addition to his mask an impossible costume. A playgoer of the day said: "His wig was so large that it swept the floor everytime he bowed, and his hat was so small that it was no wonder he carried it more in his hand than upon his head; his jabot might be called a jacket; and his canons seemed to be made only to serve as hiding places for children playing hideand-seek. A twist of tassels ceme out of his pockets as from a cornucopia; and his shoes were so covered with ribbons that it was impossible to say whether they were of Russian leather, or English calfskin. At least, you could tell they were half a foot high; and it was hard to believe that such high, thin heels could support the body, the ribbons, the cenons and the powder of the marquis."

Jodelet's face was white with flour, just as the hero's in Ia Jalousie du Barbouille. Imagine the outburst of laughter in the pit when Mascarille, introducing him to Cathos and Magdelon, said: "Don't be astonished to see the viscount so; he has but recovered from an illness which has left his face as pale as you now see it." 
This disguise of lackeys recalls the old farces. The Italian influence is seen, too, in the fact that the actors introduced their own innovations. Jodelet, bereft of his handsome olothes by his master, takes off innumerable vests (a primitive device for provoking laughter), and is found dressed as a cook; then putting on a cap, he continues to pay court to the horrified précieuses. The slapping of the sedan chair bearers by Mascarille, and the beating of the two false noblemen are survivals of the Italian comedy-of-masks. There is exaggeration almost to caricature for fun's sake. The plot is merely an excuse for the conversation between the two girls, and the two valets. Its fun is still fresh, and its gayety, irresistible. In this piece, farce took on a veracity and a significance. The richness of its satire raised it almost to the loftier level of comedy. The play was an immediate success, prices were doubled, and one year later it was presented before the young king, Louis XIV, showing his liking for Molière as an actor, and as an author.

Sganarelle followed the epoch-making Les Précieuses Ridicules. A farce in one act and in prose, it resembled the old French farces modeled on Maitre Pathelin. Traditional characters open the play by quiproquo (blunder) 
on a traditional setting, an open street with the house that of

of Sganarelle on one side and/Gorgibus on the other, and end it in an unlikely way. Rather risqué funny episodes of a frank Gallic wit intervene. The rapid movement and full color of the comedy-of-masks is present. Everyone is at cross purposes with the other. Célie, the young girl, dropping the picture of Lélie, her lover, faints from grief because she must marry an ungainly hus band of her miserly uncle's choice. "Why does she faint?" asks Rigal. "So that Sganarelle may have the opportunity to rescue her, and so that his wife, seeing him, may believe she has been deceived. Why does she drop the portrait? So that the wife of Sganarelle may pick it up, look at it, and thus make her husband suspicious." The Paris of 1660 considered the wrathful monologue of Sganarelle apropos of avenging his honor, "la belle scene" of the play. In full armor did he advance to attack Lélie; but losing courage as he approached, explained that his armor was but a costume for protection against the rain.

It is Sganarelle now who is chief fun-maker. Mascarille of I'Etourdi, of Ie Dépit Amoureux, and of Des Précieuses Ridicules has now resigned in favor of a more real successor. Sganarelle wears no mesk, is more French, more cormonplace, more real; thus he can better personify ridiculous men of humanity. Mascarille was the cleverest of intriguers, 
the deviser of an unlimited number of jests, always playing jokes on others while Sganarelle is a fool, and the victim of his own blunders. Molière made the part farciel by his funny postures and gestures. Mimiory and mummery made the old jokes interesting. This piece, unassuning and amusing, was long the most popular of Molière's plays. It marked no special advance except one, - jealousy is expressed in Sganarelle. It is jealousy presented in its comic aspects, it is true, but an emotion, nevertheless. Thus laughter was aroused by character as well as by situation.

In many respects, L'Ecole des maris is another farce. Sganarelle, this time an uncle, is again the most important character, and again very funny. The action and the denoument especially show the farcial tendency. Certain fixed types, the lover and his valet, a pair of pretty girls, and an outspoken sewing girl; and the customary street scene reveal the form of the comedy-of-masks. But Noliere used this framework and these fixed types for a sincere portrayal of the manners, and of the people of that time, and also as a means for social criticism. Although there is some buffoonlike mimicry in the actions of Sganarelle and the valet, they have real traits of character. Sganarelle is this time enriched by the characteristies of the bourgeois class. And at times 
he appears surly. Ariste is the first of Molière's characters to act as the example of bourgeois sobriety which he was to use later to express sturdy common sense. None are simple farce characters. Another departure is the use of stage names; Ariste, Léonore, Valère, Ergaste, and Lisette are the actors.

Isabelle, one of the pretty girls, is clever. Valère, having failed to win her, is aided by her ruses. She approaches Lysidas, her guardian, with: "There is a certain young man, Valere, who is pursuing me. Go tell him that I have noticed it, but that I am a good girl." Valère understands Isabelle's intention in spite of the coups de boutoir. But Isabelle, fearing that Valere has not understood, decides to write. Sganarelle is sent again, this time with a box, a chicken, and a letter, which, she says, Valere had thrown into her room. Finally through another of her ruses, she succeeds in getting Sganarelle to bring Valère before her house, and to thus produce the famous scene in which she embraces her guardian so that Valère, who is standing behind, may have the chance to kiss her hand. Then Sganarelle, ignorant of the whole affair, turns to embrace Valere by way of reconciliation.

These ruses of Isabelle are to show the bad effect of her convent-like training imposed upon her by Lysidas. The theme that Molière develops is that bolts and 
bars played too large a part in the education of girls of the old regime, and that freedom would produce honesty. For a season now, Molière ceased his trade of playwright, perhaps, to enjoy his matrimonial adventure. From his experience developed $\mathbf{I E c o l e}$ des Femmes, reflecting the fragrance of that happy season, full of zest, nerve and sympathy for young love. A contagious gayety pervaded the whole play. The author was still holding fast to the Italian formula, that is, there was the public square in two houses of which the characters, more or less types, resided. The farcial element had part in Act $\mathrm{V}$, Scene, according to the Critique de I'Ecole des Femmes, which appeared to counteract the abundant criticism caused by the presentation of I'Ecole des Femmes. Lysidas asks in the Critique: "Didn't Monsieur de la Souche go too far with those extravagant rollings of the eyes, his ridiculous sighs, and those silly one tears, which make every/laugh?" The grimaces of Armolphe, the mocking geatures of the notary behind Amolphe's back - a scene hardly permissable in the meanest of farces - simply prove that if the end to which Moliere hoped to attain is higher, a great number of means are essentially the same. The notary scene was inserted for mere laughter. The subject founded upon a Gallic theme - the fear of misalliance - the bourgeois medium, the traditional characters, all recall farce. 
The mots bouffons of Agnes, the ingenue, shocked the delicate. They can be excused in servants who in

play a burlesque role but not/Agnes. Rigal criticises

Moliere for catering to the tastes of the parterre in his broad jokes which provoke an ugly laughter.

But, if these episodes dip partly into farce, they are raised, for the most part, above it. The most salient features are those of the comedy-of-manners, and of the problem play. The opening quiproquo has a trait of character as its cause. It affords the same pleasure as I'Ecole des Maris by its surprises, humor, ingenuity; but after laughter comes reflexion. Molière still a farceur is also a penseur. In spite of its more or less mechanical plot, the characters are real. Armolphe is made grotesquely absurd in his inability to see himself. He is fiercely jealous, and even foolish in his egotism; yet the spectator feels sorry for him. He is not a puppet to cause empty laughter. Laughter is brought about by comic characters in comic situations.

When the king conmanded, Molière must cease his ow activities to provide pleasure for the court. His plays fashioned for the public had been witnessed and applauded by the court; but it could enjoy much more diversions which catered wholly to its tastes. The comedy-ballet or farce set to music, a new species of play, was undertaken by Molière. This genre he judged an appropriate frame for les agrements, that is, the music and dancing, now pompous, 
now comic, which delighted the nobles so much. Les Facheux was the first of this type,

little more than a series of episodic scenes. Trees and statues grace the stage. Molière, in street dress, advances anxiously, saying that he is very worried because his actors have not appeared. Suddenly, a great shell opens, from which comes a numph to dance, and to say that the trees and statues will replace the actors who have failed to appear. Whereupon dryads, fawns, and satyrs awake and dance to the sound of oboes and violas. Dorante, the hunter, enters in enormous boots and a long plumed hat, striding, and gesticulating exuberantly, and talking in a ridiculous manner of the hunt. Still raving indignantly, he is interrupted by the entrance of dancing gardeners, archers and bowlers. All seem to be having a jolly good time.

Throughout the play floats Eraste, the lover, forever separated from his beloved by troublesome bores. The theme is a daring and novel way to present the stupid courtiers of the day, caught at their insipid gallantry, and held up to laughter. Generous fun is made of the beribboned and foppish fine lords with heads as empty as their bodies are beribboned. We see them exhibiting their false, gushing embraces to men they do not know. Their impolite actions upon the proscenium are criticised. The more humble fâcheux 
are none the less spared. Caritides, the pedantic scholar, claims for himself as position as inspectors of signs and inscriptions to censure and forbid their barbaric orthography. Ormin has found a means of reducing taxes by making ports of all the coasts. This aristocratic piece was not far from farce. Such a subject had been treated by the Italian farceurs with Pantaloon, Flaminia and Scapin. Another of these comedy-ballets, Le Mariage Forcé, presented Sganarelle to the king. He is the same fixed type, and affords genuine comedy in his perplexities. The scene is an open square. In Act I, Sganarelle falls asleep; and in a dream there appear to him Beauty, who sings to him; and Jealousy, Sorrows, and Suspicions, who do a restless dance. dance.

Plaisants or Goguenards (clowns) do a mocking. In the second act, a Magician sings, demons and gypsies gambol about, answering the questions of Sganarelle only by the movements of their bodies. Rich humor is shown in the Philosophers. Under the features of Pancrace, appear our old acquaintance, the Italian dotter, the doctor of Ia Jalousio du Barbouillé. In this joyous piece where farce is apparently the maddest and most traditional, Moliòre gave pictures of real people in stinging satire.

\section{La Princesse d'Elide, written for the}

monarch's pleasure to form a part of the week long spectacle, The Pleasures of the Enchanted Isle, was not characteristic of 
the author, not worthy of him. This was closely followed by another comedy-ballet in three acts and in prose, and celled I'Amour Medécin. An open street before the house of Sganarelle, the usual type, shows the framewrork of the . oomedy-of-masks. He is an obstinate, old widower who wants to keep his daughter, Lucinde, for himself. Not desiring matters to remain thus, she feigns illness, whereupon Sganarelle sends a servant for four doctors who come dancing in. Understanding nothing of their pedantic harangue, Sganarelle seeks to buy drugs of a quack, when singing and dancing buffoons and scaramouches surround him. In the third act, Clitandre, the lover of Lucinde, and himself, the fifth doctor, brings in patient. Singing and dancing conceal the singers and instruments to dispel the melancholy of the/departure of Lucinde. When Sganarelle suddenly perceivers her absence, his attempt to rush in her pursuit is prevented by the dancers. The marriage contract had been signed by a notary, whom Clitandre introduced as a secretary whose duty it was to write his preseriptions. As the play advances, the scenic plays, and the jokes of farce increase.

This unpretending little faree, brisk and lively in movement, significant only as an example of Moliere's fertility, is his first to declare war on medioine. The four physicians were four of the leading doctors at court. He was not attacking their persons, but the medical profession. He did not seek to misrepresent the doctor but to paint him 
in true colors. Investigation of the medical profession of that period shows that the queer dress and faces, and the pedantry of the doctors would prove highly laughable on the stage. The doctors of this piece are types of their special profession who provide laughter at the expense of their characteristic pedantry. Farce is a gain the vehicle of social satire and the public is enjoying it.

Laughter is heard only here and there in Don Juan. Although not comic in theme, Molière called it a comedy. Nevertheless, Don Juan, the gay, clever, libertine, and mocking eynic, is not to be laughed at. The valet of Don Juan is Sganarelle, who differs in appearance and character from the other Sganarelles. He is a cowardly servant with a penetrating shrewdness, used mostly to show Don Juan's character. He supplies the farcial bit with his nonsensical talk, his naive replies, and witticisms, and his facetious tricks played on the other valets. In one instance, Sganarelle's mouth filled with stolen meat gives ksan the appearance of a swelling which Don Juan insists on piereing with a lancet; plates are snatched away no sooner than filled. These are tricks which have remained classic upon the fair trestle. The part allotted to farce is completed by the language of the peasants, the jeu de scene in which Pierrot hides while crying out that he is not afraid, and the slaps, which he receives. In spite of all this, Molière was reserved in his mirth. He was too absorbed in ascribing to the tradi- 
tional Don Juan of the Spanish, the characteristics of the court nobles.

The loftier the play, the less is seen of the comic element, although Molière's natural liking for farce, the naturally gay disposition of his youth worked for the cheering up of his most serious subjects. Tartuffe, 10 Misanthrope, and les Femmes Savantes are all models of high comedy. Of these three new dramatic formulas, Tartuffe has the superabundance of the comic, which acts as a skillful counterpoise to the dramatic part. It gave the contemporary playgoer abundant laughter. The fun it provided was not that of the comedy-of-masks; for in this play Moliere appeared entirely free of the Italian frame. The atmosphere is decidedly French; the characters are not fixed types, but highly colored, and alive; the scene is not an open square, but the home of a French family. Dorine, the maid, lightens the scenes as Mascarille had lightened the plays in which he appeared; but Dorine is as veracious as Mascarille was fantastic. Madame Pernelle, the mother, was played by the cripple, Joseph Bejart who burlesqued the role. Flipote, her servant, becomes the object of the farcial slap when he refuses to hurry at his mistress's command. Therein figure the partridge, and the gigot ( $\operatorname{leg}$ of mutton), which one dares to eat only in farces; therein figure certain jeux de scène in which Dorine is always in danger of receiving a slap on account of 
her habit of interrupting her master, Orgon, continually. Dorine predicts the easy jokes of our vaudevilie stage. The scene in which Tartuffe drives out Damis, the son of the house, is made ridiculous by the antics of Orgon. Molière expected Tartuffe to be laughed at; for in his preface we read: To expose them to the laughter of everybody is a great attack on vice. Tartuffe is depicted as a holy man, not presented in a ridiculous fashion. If he causes laughter, it is because of his false position. And the audience did laugh heartily at him. This could not have been unthinking mirth; for the spectator was laughing at fun caused by the reaction of character.

A so-called comedy-of-character, Tartuffe blends together the comedy-of-character first, then the piece a these, the comedy-of-menners, the comedy-of-intrigue and farce. Rigal indicates that farce is at the very basis of the work. To the reader, however, farce seems to yield first place to the problem of the play - hypocrisy, and its unmasking. Affectation in any form offended Moliere. Such a thing as hypocrisy stalking boldly under the cloak of religion, Moliere could not stomach. Farce was used whenever it was necessary to relieve the semi-tragic situation.

In Ie Misanthrope, there is no Dorine, no Madame Pernelle, no Orgon. There is a Monsieur Dubois, it is true, to ease the tension at times of the greatest emotion. 
At the end of Act IV there is one scene of pure farce. Alceste, the misanthrope, has just made violent reproaches to C'elimène, the coquette; a victim of a love he cannot conquer, he has just spoken to her in a stirring speech, mingled with love, fury, and sadness. Comedy is approaching tragedy when Monsieur Dubois appears in a queer attire, looking for his master. Dubois is frightened, makes mysterious movements, and stammers so that his master's patience is exhausted. Finally, they succeed in gotting out of him that he has a very important paper for Alceste. He looks for it everywhere, but does not find it. Suddenly, he exclaims, "My faith, I have left it at home!" This comic element is less artificial, less gross. The spectator "laughs in his soul" as Donneau de Visé has said. Some of the exaggerations of Alceste's character evdke the smile rather than the laugh. "The play is too serious", said the public, "since it is comedy, it should provoke laughter, and it does not provoke enough."

\section{From this height, the detailed painting}

and study of character in which comedy was forced to contain the deeper views of life, Moliere descended to the level of farce. A series of lighter plays now followed, full of fun and with plots made merely to provolce laughter. This 
stratagem must be used to draw back the public. The Parisian theatre-goer was not yet well enough trained in the art of drama appreciation to enjoy such a serious play as Ie Misanthrope. This fact, and Molière's relish for buffoonery led him back to farce, the dramatic form in which he always felt at ease.

Le Médecinmalgré lui, the first of this series, was an elaborate reworking of his earlier farce, Ie Fagotier. The plot aims at nothing more than a rapid succession of laughter-provoking scenes largely at the expense of the medical profession. The settingt, that of the comedy-of-masks, with the house of the heroine's father where the characters of the Italian type exhibit their antios. Sganarelle is onthis occasion a wood cutter who has the bad habit of beating his wife, Martine. She, to get even, informs two lackey\$s, Lucas and Valère, who are in search of a doctor, that Sganarelle is one, but that he has to be urged by a sound thrashing before he will acknowledge the fact. Another pretext for the use of the bâton, so loved by the Parisian audience, Sganarelle, turned doctor, makes love to Jacqueline, the pretty wife of Lucas, and feigning to embrace Lucas, he kisses his wife, who is near him. Luces gives him a push, sending him whirling round and round; Jacqueline, in her turn, pushes Luces, who also begins to whirl. Lucinde, with her "Han, hi, hom, han, han, hi, hom", 
the only words which her strange illness permits her to say, must have delighted the theatre-lovers of that time. Sganarelle is so pleased at curing Lucinde that he decides to remain a physician, since it is an easy, suitable and safe profession. Of course, Sganarelle has ample opportunity to use the few Latin words he knows, in a most ridiculous fashion. Every character was out for a good time, for fun spontaneous, and exuberant.

Voltaire made the criticim that the Médecin malgré lui was "a very gay and buffoonlike faree" made "for coarse people"; and that "the sage must disguise himself as a farceur to please the public". This disguise was assumed very gracefully and decked in the most sparkling wit, according to the Despois et Mesnard edition of Molière's works. The characters have such veracity in spite of their exaggeration, and on account of their fresh, vigorous dialogue that it is amost comedy. The Gallic wit pleased the bourgeois who liked broad fun. It charmed even the higher classes, who had liked le Misanthrope.

Moliere exploited the past for facetious subjects. Le Medecin malgré lui shows the influence of Ie Vilain Mire, and of a later piece, Ie Voyage on Moscovie. The idea of rustic wife-beating was found in the old fabliaux of the Middle Ages. Some of these old farces made fun of doctors. The doctor farces never lacked buffoonery and grotesqueness. But Moliere gave more bite than any to the 
Gallic salt.

As George Dandin in the play of that name, Moliere swept everything along in a whirl-wind of gayety, pushing his character to the edge of caricature. Though a farce in form, and content, and though contemporary reports agree in recording the incessant laughter of the audience, nevertheless, the play is almost tragic in its domestic calamity. In the words of Coleridge, farce "may often border on tragedy, indeed farce is nearer tragedy in its essence than comedy". All George Dandin sees before him is suicide, because of his wife's immorality. At this point, the friends of Bacchus dance in and drag poor George off with them, and thus the play ends.

All the characters are more or less repellant. The last act is almost that of Ia Jalousie du Barbouillé. Lubin awkwardly tells George that his wife, Angelique, has been outside at night in conversation with clitandre, a gallant. George notified his father-in-law. In the meantime Angélique pretends to kill herself. As George comes out to see what has happened, she slips in, and locks the door in his face so that when her parents arrive, he seems the guilty one. In the two preceding acts, there is a confidence of Lubin, an appeal by Dandin to his father-in-law, and honorable amends made by the husband.

This monotony is relieved only by the variety of incident, gesture and word. Angélique bows and makes 
signs to a handsome gentleman, which the husband thinks are intended for him; she feigns to beat a gallant, taking care that the blows fall upon her husband as if by accident; in the darkness, people seeking one another, continually get the wrong one, or bump into one another. George's whole misfortune is due to his misalliance with a demoiselle above his station who disdains him. Molière thus shows his scorn for a peasant who aspires to nobility. And George, himself, says, "Ah! what a strange affair is a young lady of the nobility, and what a lesson my marriage should be to all peasants who aspire to rise above their condition". L'Avare, presented the same year is another semi-tragic domestic drama whose sadness is relieved by a pair of love stories, almost farcial in their humor. Elise, his daughter, whom he has promised to Anselme, an old man, has declared her love to Valere. This discovery of his daughter's action oocurs at the very moment then the treasure box of the avare has been stolen. Everything Valère says about Elise, Harpagon, the avare, thinks, pertains to his treasure chest. A very funny scene this proves to be. It recalls the "Aulularia" of Plautus. Harpagon is in love with a young girl Marianne, who is secretly loved by his son, Cléante. While Marianne is visiting Harpagon, cleante puts his father's diamond ring on her finger. Then follows a very comical scene caused by the despairing gestures of Harpagon as he tries to regain his jewel. 
Moliere inserted the comic element intothis avaricious old man by contrast between what he ought to do, and what he does; by his stupidity which works destruction to his avarice; by his expressive exaggerations, repetitions, and gesticulations. Harpagon, of the wealthy bourgeois class, must needs have a staff of household servants suitable for his station in life. We would expect him to keep his servants presentable; on the contrary they are ragged and hungry. Maitre Jacques is both cook and coachman. His horses are so ill-fed, they cannot pull his carriage. When he is to give a dinner, we expect a plantiful meal; but all the guests have to eat are stewed beans. His excuse is that frugality is best for the stomach. The way in which he manages his household provides much of the comic element. If taken seriously, the story is one of sordid avarice, and odious disrespect. If taken lightly, its moments of exaggeration and extravagant humor afford some laughter, but not the laughter of pure farce. Geothe considered it "tragic to a high degree". In fact, cleante, borrowing from the agent of a usurer, who, in reality, is his father, promises that, if necessary, he will see to it that his rich father dies before six months. And Harpagon, on hearing the news, and not realizing that he is to be the victim, says, "Now, that is something." When the borrower and usurer meet, we see a very angry father and a disrespectful 
son. Even here Molière avoids drama by arousing in the spectator that mixture of surprise and expectation which is favorable to laughter; and by the funny reproaches addressed to each other. Molière had recourse to "comical hors-d'oeuvre", as Rigal puts it, and to farce tricks to dispel tragedy. In a monologue Harpagon weeps, cries, groans, almost frightens the spectator; but here and there, the author inserts an exaggeration, a funny word or an unexpected appeal for help from Harpagon to the audience. Very tragically, Harpagon exlaims: "It is all over, I am undone; I an dying; I am dead; I am buried," and then interposes "Won't somebody ressuscitate me by getting my money for me?"

$$
\text { Maitre Jacques recalls the clowns of the }
$$

fair stages. The spectator feels that he is added merely to cheer up the play. He is rather unreal, but is needed to dispel the gloom which would otherwise be too great. Granting that he is fantastic, we may have a good laugh at his actions.

Molière has showed his marvelous art in making this tragic subject fit a comic mold. His language was never more frank, more brilliant, more transparent; it was never better fashioned to show truthfully and forcefully all the feelings it wishes to express. L'Avare is one of the best works of Molière. Harpagon is the most carefully developed and most complete of all Moliere's characters. 
In 1669 the court retired to the chateau de Chambord to spend September and October. Molière accompanied them there to produce for the king Monsieur de Pourceaugnac, another comedy-ballet. Its hunor arises largely from the ingenuity of the mechanism of its situations; but Pourceaugnac is a more recognizable human being than Mascarille. The conedy-of-masks again offers its services with its mt of stock characters: Sbrigani, wily valet, Eraste, the lover, Oronte, the old man. The apothecaries who pursue him are an excuse for the comic chorus and dance. But Pourceaugnac is a provincial whose rustic contrast with the Parisians makes for the fun. Sbrigani complicates matters with his lies and tricks, each more amusing than the preceding one. He tells Oronte that Pourceaugnac, a suitor for his daughter, Julie's, hand, is heavily in debt; and he tells Pourceaugnac that Julie's reputation is not above reproach. Through the contrivance of Sbrigani, a woman from Provence with several small children, then a woman from Picardy with hers, besiege Pourceaugnac with ories of "Bapa". These provincial types Molière had seen in his youth as a wandering actor. Sbrigani also holds a consultation of lawyers who give their song and dance. Then he aids Pourceaugnac, disguised as a woman, to make his escape. The fun is the result of a series of practical jokes; but a certain development is seen in their closer relation to the play. A streak of coarseness is 
found here and there in the free, spontaneous fun. As Brander Matthews says: "Molière's idealism is not squeamish; it does not shrink from the baser facts of life." He possesses a wholesome animality."

Again in October of 1670 , the court withdrew to Chambord to hunt, dance, and lull their minds with pleasure. A comedy-ballet of daring and fantastic buffoonery was the only formula suitable to the mood of the court. So Ie Bourgeois Gentilhomme was filled with "carnival gayety", as Monsieur de Pourceaugnac had been. Not only is the central figure a living being, but the other characters, too, are recognizable human beings. Jourdain, a wealthy bourgeois, ambitions to rise above his present rank, is a constant source of laughter with his persistant trying to make himself a gentleman by the study of music, diction, philosophy and fencing. An unworthy Turkish envoy in Paris and an account of oriental life by a traveler provided the subject for the most extravagant episode, a caricature of Turkish manners and customs. This scene also affords entrance to the dancers. A Turkish priest invoking Allah, and a muphti, uttering strange formulas, sing and dance. The first three acts are equal to the best of Molierre's character-comedy; the last two are almost nothing but pantomimic farce with their extravagant buffoonery and grotesque exaggeration scarcely in keeping with the rest of the play. It is called a "hybrid of comedy and farce, and burlesque" by Brander Matthews. It lacks the 
logical construction of Monsieur de Pourceaugnac.

Les Fourberies de Scapin, written in the last years of Molière's life, once more did honor to the comedyof-masks mingled with Gallic farce such as he presented it in the provinces. Scapin is Mascarille under a new name, incomparable in his roguery and in the audacity of his tricks played upon the two fathers. However, the play is only superficially like his earlier masks. It is more ingenious and less mechanical than l'Etourdi; its humor is richer, its gayety more spontaneous; its characters are more veracious. The fathers are true human beings. When the fun is carried far enough, the plot is brought to a sudden, happy end, by the intervention of chance, which plays an important part in the unraveling of imbroglios in Molière's plays. Scapin is not skillful enough to disentangle matters.

The play itself is but one of fantasy. If taken seriously, the moral and physical atrocities of Scapin would be indecent. It is as grotesque in its cruelty as Punch and Judy if they were looked upon as real. The fact that the scene is laid in Naples, a distant place, adds to its unreality.

"Are we in Italian comedy or are we in farce?" asks Rigal. It is impossible not to recognize the farcial element in its text, given over to the fancy of the actor; its masked old men; and its famous sack scene, a relic from Gorgibus dans le sac. "The spadassin brother of Hyacinte 
wants to kill you" says Scapin to Geronte; "he has hired all sorts of spadassins, like himself, and soldiers. Get in this sack" Once he is inside, Scapin has a merry time, imitating the Gascon, and the Swiss patois, and the voices of fifteen men, and under protext of defending his master and receiving blows himself rains down a deluge of blows upon the sack and Geronte. This was called "gross buffoonery" by Auger. Boilean was scandalized. Molière displayed all aspects of the comic, the highest as well as the lowest. Les Femmes Savantes forsook the realm of farce to enter that of high comedy. It is a problem play, the higher education of women. Its action is caused by the elash of character upon character. It is a bigger, more human Précieuses Ridicules. The characters in Les Précieuses Ridicules fell short of nature, but these prudes are true to life. There is no borrowing here. Humanity is the model. The audience is diverted by these femmes savantes. The play is humorous, full of an intellectual play of wit. Thus the laughter must be a more thinking laughter, caused by more elevated mots de caractere, and mots de situations. In the words of Voltaire, "the more you see it, the more you wonder how Molière could put so much of the comic into a subject which seems to furnish more pedantry than pleasure. The last piece in the repertory of Moliere was mother of those tragic farces. Its theme is somber, 
but is so carefully covered up by funny scenes that the spectator does not realize its tragedy until after the play is over. Behind its exuberant gayety, there is a feeling of something sinister. Its title, Ie Malade Imaginaire, designates nothing gloomy; on the other hand it prepares one to expect fun. We find there is nothing wrong the Argan, the malade, except his belief about himself, and that all he noeds is a mental healing. Diafoirus père, and Diafoirus fils, caricatures of the medical profession heighten the farcial color with their high-sounding solemnity and the profuseness of their barren learning.

When Argan decides to become a doctor, then the fun is fast and fantastic, ending in pure buffoonery. Béralde reveals to Argan that once the cap and gown are donned, he will find himself endowed with all the learning of the medical profession. Here words give way to song and dance. Upholsterers frolic in to prepare the room for the reception of the new doctor. Soon a long procession makes its appearance: eight apprentice apothecaries with their instruments, six apothecaries, twenty-two doctors, singing and dancing. They are greeted by the presiding physician in "macaronic Latin" (as Branden Matthews expresses it), who confers upon Argan the full powers of the profession to purge and kill and bleed throughout the entire world. An investigation of medicine of that period proved that this scene ressembled the customs of the School of Medicine at Montpellier. Dandet 
found in the play an "unmistakable flavor of the south of

France." This flavor is evident in the buffoonery and grotesque exaggeration of the final opisode. 
C ON C I U S I N 
Thus again and again after attaining the heights of the modern drama, Molière descended to the level of farce, a form in which he always felt at ease, and which he relished for its bold buffoonery. He liked to let his comic verve, one of his natural gifts, run on unbridled. The Despois-Mesnard edition states that the name of farce is always applied with considerable difficulty to a play of Molierre's unless it is reserved for those little canevas, or bits of buffoonery he played in the provinces. This is true, if when we use the word farce we mean to indicate the old traditional type. Farce in the hands of the great dramatist gradually took on almost all the color of comedy. Through his influence, farce has changed its meaning. In the provinces, he appropriated the form of the semi-acrobatic comedy-of-masks, and a store of observations of human nature. He combined the two, together with what he had assimulated from the French farces, and Spanish literary comedy to produce his little masterpieces of comedy.

$$
\text { Gayety, animation, and swiftness characterize }
$$

his first attempts. They reflect the happy carefree life of the youthful wandering actor under southern skies with his beloved Nadeleine Bejart. His humor is more external, 
less subtle, less rich, arising from mere ingenuity of artificial situation. The characters serve as little more than merry puppets placed under the stress of circumstances. Not long did they rerain marionettes moved by the hand of the author, but began to take on characteristics of their own, and to regulate their own actions. Molière went along gradually, feeling his way and seeing whether or not the public was following. As he gained more confidence in himself, he put into his pieces more and more truth and less and less fantasy. Not until Tartuffe did he give up completely the Italian frame. Rather than let it go suddenly, he infused into it first the comedy-of-intrigue, then the comedy-of-manners, then the comedy-of-character, and then the problem play. Whenever the public was not close upon his feels as was the case with le Hisanthrope, he again resorted to the simpler form.

As Molière advanced in years, the heavier and more dramatic plays did his pen produce. Then some unpretentious farce, sometimes almost a mask would appear to show that its author still liked hearty laughter. Molière is said to have been rather melancholy as a man of forty. Chapelle, one of his dearest friends, was always urging him to be less serious, to be more like the merry, happy-golucky characters he set upon his stage. But Molière never 
seemed to have heeded this advice. However, he was not a misanthropist, did not hold aloof from society. Rather, did he keep in close touch with men. In Paris his house was always open to his friends, his table always set for his friends. His married life and temporary failures must have made him more meditative, less carefree, but never enough so to forget his public whom he sought to please first of all. Besides, Molière was a Frenchman, and the Frenchman is sociable. He likes to stand well with his fellows.

Moliere had to keep in close touch with men to furnish his gallery with such varied types, and to give them their characteristic actions by which they are remembered. Truth was Molière's goal. He presented it in the sugar coating of exuberant humor that the public would swallow it. He held up humbugs to scorn by making paople laugh, not criticising the person but his marked vices. He has also created a delightful world of gay, witty creatures, whose function was to cause fun for fun's sake. The language of these characters is always true to its type, often disdaining rules of gremmar and rhetoric for taste and vigor.

To convey humor, Noliere first used the mot desprit or witticism pure and simple, and detachable 
from the text. But this was soon cast aside for the mot de situation and the mot de caractere, which are dependent upon the play itself. The mot de situation is funny only in its proper place in a play. It is caused by the development of the play. The mot de caractere is a phrase which makes us laugh because it is the intense expression of the individuality of the person who speaks it. Thus as the situation becomes more varied and as the characters beconesmore alive, we see more of this kind of wit of a more thoughtful nature, and even on that account more comical. 


\section{Bibl log raphy}

Barrett

A Study of the Modern Drama,

Chatfield-Taylor, H. C., Moliere a Biography New York, 1906

Faguet, Emile, Dix-septieme sieole, Paris n.d.

Lynd, Robert, Books and Authors, New York, 1923

Mat thews, James Brander, Moliere, his Life and Work New York, 1910

Mercier, L. S., Moliere, drame, n. pl., n.d.

Rigal, Moliere, Paris vol I, II 